\title{
Resilience levels among adolescents with ADHD using quantitative measures in a family-design study
}

\author{
Níveis de resiliência em adolescentes com TDAH: um estudo de família \\ utilizando medidas quantitativas
}

Maria Angélica Rates Regalla, ${ }^{1}$ D Daniel Segenreich, ${ }^{1}(\mathbb{D})$ Priscilla Rodrigues Guilherme,${ }^{1}$ Paulo Mattos ${ }^{1,2}$

\begin{abstract}
Objectives: To investigate resilience levels in adolescents with attention-deficit hyperactivity disorder (ADHD) using quantitative measures when compared to their non-affected siblings and controls. We also aimed to investigate the correlation between resilience and depression, anxiety, intelligence quotient (IQ) and socioeconomic status, which may affect resilience levels and be potential confounders.

Methods: Adolescents $(n=45)$ diagnosed with ADHD referred to an outpatient ADHD clinic, and their siblings without ADHD $(n=27)$, with ages ranging from 12 to 17 years, were interviewed along with their parents using a semi-structured interview (Children's Interview for Psychiatric Syndromes - Parent Version). Intelligence was measured with the Block Design and Vocabulary subtests from the Wechsler Battery. Anxiety and depression were investigated using the Children State-Trait Anxiety Inventory (CSTAI) and the Child Depression Inventory (CDI), respectively. Resilience was investigated using the Resilience Scale. A control group (typically developing adolescents [TDA] and their siblings; $\mathrm{n}=39$ ) was recruited in another outpatient facility and at two schools using the same methodology.

Results: Socioeconomic status and intelligence levels, which may affect resilience, were similar in all groups. Adolescents with ADHD showed lower resilience levels compared to siblings and TDA even when controlled for anxiety and depression levels, which were higher in ADHD. Resilience levels were higher in siblings than in adolescents with ADHD, and lower than in TDA this last result without statistical significance.

Conclusion: In our sample, ADHD in adolescents was associated with lower resilience, even when controlled for confounders often seen in association with the disorder.
\end{abstract}

Keywords: Resilience, adolescents, attention-deficit hyperactivity disorder.

\section{Resumo}

Objetivos: Investigar níveis de resiliência em adolescentes com transtorno do déficit de atenção/hiperatividade (TDAH) empregando medidas quantitativas de modo comparativo a irmãos não afetados e controles. Também se investigou a correlação entre resiliência e depressão, ansiedade, quociente de inteligência (QI) e status socioeconômico, que podem afetar os níveis de resiliência e atuar como confundidores potenciais.

Métodos: Adolescentes $(n=45)$ diagnosticados com TDAH e encaminhados para um serviço ambulatorial de TDAH e seus irmãos sem o transtorno $(n=27)$, com idades entre 12 e 17 anos, foram entrevistados junto com seus pais utilizando-se uma entrevista semiestruturada (Children's Interview for Psychiatric Syndromes - Parent Version), em português). A inteligência foi mensurada com os subtestes Blocos e Vocabulário da Bateria Wechsler. Ansiedade e depressão foram investigados com o Inventário de Estado-Traço Infantil [Children State-Trait Anxiety Inventory (CSTAI)] e o Inventário de Depressão Infantil [Child Depression Inventory (CDI)], respectivamente. A resiliência foi mensurada utilizando-se a Escala de Resiliência. Um grupo controle [adolescentes com desenvolvimento típico (ADT) e seus irmãos; $n=39$ ] foi recrutado em outro serviço ambulatorial e em duas escolas, empregando a mesma metodologia.

Resultados: $O$ status socioeconômico e os níveis de inteligência, que podem afetar a resiliência, foram similares em todos os grupos. Adolescentes com TDAH apresentaram menores níveis de resiliência comparados aos seus irmãos e a ADT, mesmo após ajuste para níveis de ansiedade e depressão, que eram mais altos no TDAH. Os níveis de resiliência foram mais altos em irmãos do que nos portadores de TDAH, porém menores que em ADT - este último resultado sem significância estatística.

Conclusão: Em nossa amostra, adolescentes com TDAH apresentaram menor resiliência, mesmo após controle para confundidores habitualmente associados ao transtorno.

Descritores: Resiliência, adolescentes, transtorno do déficit de atenção/hiperatividade.

${ }^{1}$ Instituto de Psiquiatria, Universidade Federal do Rio de Janeiro (UFRJ), Rio de Janeiro, RJ, Brazil. ${ }^{2}$ Instituto D'Or de Pesquisa e Ensino (IDOR), Rio de Janeiro, RJ, Brazil.

Submitted Sep 14 2018, accepted for publication Jan 172019.

Suggested citation: Regalla MAR, Segenreich D, Guilherme PR, Mattos P. Resilience levels among adolescents with ADHD using quantitative measures in a family-design study. Trends Psychiatry Psychother. 2019;41(3):262-267. http://dx.doi.org/10.1590/2237-6089-2018-0068 


\section{Introduction}

The ability to adapt to adverse experiences varies to a great extent among individuals. Resilience is considered to be the positive end of this spectrum of adaptation: resilient individuals maintain healthy adjustment and manage to avoid psychological collapse when faced with adversities. ${ }^{1}$

Resilience as a construct has undergone significant changes over time. Once considered as a characteristic of the child (i.e., a trait), it is now understood as a dynamic process of positive adaptation in the context of significant adversity, depending on two constructs subsumed under its definition: risk exposure and good adaptation. ${ }^{2-5}$

Risk factors include both psychosocial (poverty, maltreatment, traumatic events, etc.) and nonpsychosocial (prenatal insults, diseases, etc.) elements which increase the likelihood of a maladaptive outcome. Many individuals manage those adversities without deleterious consequences, while others do not, even when faced with the same risk factors. ${ }^{6,7}$ Because resilience is not a static construct, it may change whenever circumstances modify. ${ }^{8}$ In summary, resilience can be defined as a dynamic process through which a person thrives/copes/deals with events and risks in the context of his personal characteristics, familial, social and cultural history. ${ }^{9}$ Correlates and causes of resilience have been searched by many research groups, mainly focusing on psychopathology and cultural issues.

Attention-deficit hyperactivity disorder (ADHD) is characterized by inattention, impulsivity and hyperactivity. It is one of the most common reasons for referral to mental health services in childhood and adolescence ${ }^{10}$ and is often associated with poor outcomes. ${ }^{11}$ Children with ADHD who were being treated for their disorder still experienced poorer health and lower subjective well-being compared with typically developing children. ${ }^{12}$ However, similar to what is seen in other psychiatric disorders, there is significant heterogeneity in outcomes of children and adolescents with ADHD, and many different factors have been investigated regarding their contributing role. Of note, there is a paucity of studies investigating resilience levels in ADHD using quantitative assessments of resilience ${ }^{13}$; instead, a few studies address resilience through indirect proxies like stressful life events and dysfunctional beliefs. ${ }^{14}$ According to Dvorsky \& Langberg, ${ }^{15}$ social and family factors comprise the most contributing factors promoting resilience in ADHD. However, most studies on resilience levels do not use quantitative measures and do not investigate factors associated with the disorder, like comorbidity. In addition, few studies have a familial design, investigating resilience in family members other than individuals with ADHD.

This study aims to investigate resilience levels in adolescents with ADHD. For this, we investigated a sample of adolescents with ADHD diagnosed by experienced psychiatrists using semi-structured interviews, their non-affected siblings, and typically developing adolescents (TDA) using quantitative measures. The reason for using a family design relies on the high heritability values of ADHD and the contribution of endophenotypes for both ADHD and resilience. We also aimed to investigate the correlation between resilience and clinical aspects commonly seen in ADHD, such as depression and anxiety, as well as lower intelligence quotient (IQ) and lower socioeconomic status. ${ }^{16}$

\section{Methods}

This study was approved by the ethics committee of Instituto de Psiquiatria, Universidade Federal do Rio de Janeiro (UFRJ), Rio de Janeiro, RJ, Brazil. Informed consent forms were signed by all participants. Adolescents aged 12-17 years were consecutively recruited from an outpatient ADHD clinic at Instituto de Psiquiatria, UFRJ. All adolescents were interviewed along with their parents using a semi-structured interview (Children's Interview for Psychiatric Syndromes Parent Version [P-Chips] $)^{17}$ and diagnosed with ADHD according to criteria from the Diagnostic and Statistical Manual of Mental Disorders, 4th edition (DSM-IV). ${ }^{18} \mathrm{~A}$ control group of TDA and their siblings were recruited: a) in another outpatient facility (pediatrics) at the same university; and b) at two elementary schools, one private and one public. TDA recruited from the pediatrics facility did not present mental health complaints. All TDA were first negatively screened using the Swanson, Nolan and Pelham Questionnaire (SNAP-IV Rating Scale ${ }^{19}$ ) and then interviewed along with their parents using a semistructured interview (P-Chips) in order to confirm their ADHD-negative status.

Intelligence was measured with estimated IQ using the Block Design and Vocabulary subtests from the Wechsler Battery. ${ }^{20}$ Anxiety and depression were investigated using the Children State-Trait Anxiety Inventory (CSTAI ${ }^{21}$ ) and the Child Depression Inventory $\left(\mathrm{CDI}^{22}\right)$, respectively. Resilience was investigated using the Resilience Scale $^{23}$ adapted by Pesce et al. ${ }^{24}$ The scale is adequate for adolescents ${ }^{25}$ and comprises 25 items with Likert responses. Scores range from 25 to 175; higher values indicates higher resilience levels.

Exclusion criteria were having a diagnosis of autism spectrum disorders, mood disorders, psychosis, epilepsy 
or any other neurologic disorder, traumatic brain injury, IQ $<80$ and any previous treatment for ADHD. No TDA sibling could receive an ADHD diagnosis.

The sample was sorted into three groups according to their diagnostic status: a) adolescents with ADHD (probands; $n=45) ; b)$ TDA with their siblings $(n=39)$; and c) adolescent siblings without ADHD $(n=27)$.

\section{Results}

Analysis of socioeconomic classes (Table 1) according to official Brazilian measures (Critério Brasil26) did not reveal any differences between the groups $(p=0.317)$.

The ADHD group had a predominance of male adolescents ( 37 male; 8 female), as expected for a clinical sample in this age range. Mean age in the ADHD group (13.5 years) was somewhat lower than that of their siblings (14.8 years) and of the TDA group (14.7 years), but without clinical significance ( $<1$ year). No differences were seen in IQ levels $(p=0.184)$ (Table 2$)$.

Even though individuals from the ADHD group did not have a clinical diagnosis of depression (it was an exclusion criterion), their CDI scores (mean $[M]=9.6$, standard deviation $[S D]=5.5)$ were higher compared to TDA $(M=6.3, S D=4)$; siblings $(M=8.5, S D=4.2)$ had intermediate scores. A significant difference was seen only between ADHD and TDA, but not between $A D H D$ and their siblings or between siblings and TDA (Table 2).

Somewhat similar results were obtained regarding anxiety levels measured by CSTAI. The ADHD group

Table 1 - Socioeconomic class* of patient mothers, according to groups

\begin{tabular}{lccccc}
\hline & \multicolumn{2}{c}{ Mothers ADHD group } & \multicolumn{2}{c}{ Mothers TDA group } \\
\cline { 2 - 4 } Socioeconomic class & $\mathbf{n}$ & $\mathbf{\%}$ & $\mathbf{n}$ & $\mathbf{\%}$ & $\mathbf{p}$ \\
\hline A2 & 2 & 3.2 & 2 & 6.7 & 13.3 \\
B1 & 3 & 4.8 & 4 & 23.3 \\
B2 & 17 & 27.4 & 7 & 26.7 \\
C1 & 17 & 27.4 & 8 & 20.0 & 0.317 \\
C2 & 20 & 32.3 & 6 & 10.0 & \\
D & 3 & 4.8 & 3 & 100.0 & \\
Total & 62 & 100.0 & 30 & & 0 \\
\hline
\end{tabular}

$\mathrm{ADHD}=$ attention-deficit hyperactivity disorder; TDA = typically developing adolescents.

Mann-Whitney test.

* Based on Critério Brasil.26

Table 2 - Descriptive statistics of resilience, depression, anxiety and socioeconomic variables

\begin{tabular}{|c|c|c|c|c|c|}
\hline & $\begin{array}{c}\text { ADHD } \\
(n=45)\end{array}$ & $\begin{array}{c}\text { TDA } \\
(n=39)\end{array}$ & $\begin{array}{c}\text { ADHD sibs } \\
(n=27)\end{array}$ & $\mathbf{p}$ & Group comparisons \\
\hline Resilience & $126.1(23.0)$ & $144.4(16.9)$ & $130.5(14.7)$ & $0.001 *$ & $\begin{array}{c}\text { ADHD } \neq \text { TDA } \\
(p<0.001) \\
\text { TDA } \neq \text { ADHS sibs } \\
(p=0.003)^{+}\end{array}$ \\
\hline CDI & $9.6(5.5)$ & $6.3(4.0)$ & $8.5(4.2)$ & $0.005^{*}$ & $\begin{array}{l}\text { ADHD } \neq \text { TDA } \\
(p=0.004)^{+}\end{array}$ \\
\hline CSTAI & $42.3(16.4)$ & $21.3(10.2)$ & $24.3(13.3)$ & $0.001 *$ & $\begin{array}{c}\text { ADHD } \neq \text { TDA } \\
(p<0.001) ; \\
\text { ADHD } \neq \text { ADHS sibs } \\
(p<0.001)^{+}\end{array}$ \\
\hline IQ & $95.1(10.3)$ & $98.6(12.0)$ & $98.8(10.6)$ & $0.184 *$ & NS \\
\hline Age & $13.5(1.3)$ & $14.7(2.5)$ & $14.8(2.8)$ & $0.053 *$ & NS \\
\hline Sex & $82.2 \mathrm{M} ; 17.8 \mathrm{~F}$ & $51.3 \mathrm{M} ; 48.7 \mathrm{~F}$ & $44.4 \mathrm{M} ; 55.6 \mathrm{~F}$ & $0.001^{\ddagger}$ & \\
\hline
\end{tabular}

Data presented as mean (standard deviation).

$\mathrm{ADHD}=$ attention-deficit hyperactivity disorder; $\mathrm{ADHD}$ sibs = ADHD siblings; $\mathrm{CDI}=$ Child Depression Inventory; CSTAI = Children State-Trait Anxiety Inventory; $\mathrm{F}=$ female; $\mathrm{IQ}=$ intelligence quotient; TDA = typically developing adolescents; $\mathrm{M}=$ male, $\mathrm{NS}=$ non significant.

* Kruskal-Wallis test; ${ }^{+}$Mann-Whitney with Bonferrroni correction; ${ }^{*}$ chi-square test. 
$(M=42.3, S D=16.4)$ had the largest score, followed by siblings $(M=24.3, S D=13.3)$ and TDA $(M=21.3$, $\mathrm{SD}=10.2$ ) (Table 2). A significant difference was seen between ADHD and TDA and also between ADHD and their siblings, but not between siblings and TDA.

Quantitative measurement of resilience levels with the Resilience Scale revealed lower scores in the ADHD group and followed the same pattern observed for CDI and CSTAI. Again, siblings had intermediate scores, but this time there was a significant difference between ADHD and TDA $(p<0.001)$ and between siblings and TDA $(p=0.014)$ (Table 2$)$.

One-way analysis of covariance (ANCOVA) was conducted to compare the difference in resilience scores between groups whilst controlling for depression (CDI) and anxiety (CSTAI) (Table 3). There was a significant difference in mean resilience $\left(F_{2,93}=3.91\right.$, $\mathrm{p}=0.023$ ) between the groups. Post-hoc tests, with Sidak adjustment for multiple comparisons, showed that there was a significant difference between the ADHD $(M=126.1, S D=23.0)$ and TDA groups $(M=144.4$, $\mathrm{SD}=16.9 ; \mathrm{p}=0.036)$, while no significant difference was found between TDA $(M=144.4, S D=16.9)$ and siblings $(M=130.5, S D=14.7 ; p=0.074)$. These results indicate that even taking into account the effects of anxiety and depression, we found a significant difference in resilience scores between ADHD and TDA. Therefore, this difference could not be explained by differences in depression and anxiety scores between the groups.

\section{Discussion}

In this study, we first investigated socioeconomic differences, which can contribute to different resilience levels; our groups belonged to the same strata according to Brazilian standards. In addition, intelligence levels, which are strongly related to resilience, were similar among the groups.
Adolescents with ADHD revealed lower resilience levels when compared to TDA. Although the resilience levels of siblings were higher than those of participants with ADHD (and lower than those in TDA), there was no statistical significance to this finding; a type II error cannot be ruled out.

This result suggests that ADHD itself is largely associated with lower resilience levels, since familial factors (parenting, environment, schooling, etc.) were shared by probands with ADHD and their siblings. This is in accordance with our previous findings. ${ }^{27}$ However, siblings without ADHD had lower resilience levels when compared to TDA; this result may be interpreted from a few non-mutually excluding perspectives. First, the ADHD-related endophenotypes shared by probands and their non-affected siblings contribute to lower resilience levels. Second, shared non-genetic familial factors contribute to lower resilience. Kendall ${ }^{28}$ demonstrated that non-affected siblings of patients with ADHD reported being resentful that the family life was controlled by the child with ADHD and reported feeling powerless over the situation. Mikami \& Pfiffner ${ }^{29}$ demonstrated that sibling relationships of children with ADHD appear to be marked by higher conflict. Chang \& $\mathrm{Gau}^{30}$ demonstrated that unaffected siblings might have less family support, since their needs may be masked by their good behaviors and under-recognized by the family. Peasgood et al. ${ }^{12}$ investigated the impact of ADHD on health and well-being outcomes for patients themselves and their siblings and found that both were substantially less happy with their family and less happy with life overall. Psychopathology in parents of children with ADHD, in particular anxiety, ${ }^{31}$ could potentially affect offspring upbringing, regardless of ADHD diagnosis. Parents of children with ADHD have been shown to experience more parenting stress, demonstrate less warmth and responsiveness and have greater conflict with their children than parents of children without ADHD. ${ }^{32,33}$ On the whole, ADHD may

Table 3 - Pairwise comparisons (ANCOVA), dependent variable: Resilience.

\begin{tabular}{|c|c|c|c|c|}
\hline & & Mean difference & Standard error (a)* & Sig \\
\hline TDA & $\begin{array}{c}\text { ADHD } \\
\text { ADHD sibs }\end{array}$ & 13.816 & 5.405 & 0.036 \\
\hline ADHD & $\begin{array}{c}\text { TDA } \\
\text { ADHD sibs }\end{array}$ & -1.835 & 5.301 & 0.980 \\
\hline ADHD sibs & $\begin{array}{l}\text { TDA } \\
\text { ADHD }\end{array}$ & -11.981 & 5.271 & 0.074 \\
\hline
\end{tabular}

ADHD = attention-deficit hyperactivity disorder; ADHD sibs = ADHD siblings; ANCOVA = analysis of covariance; TDA = typically developing adolescents. Sidak. 95\% confidence interval. (a) adjusted for multiple comparisons (depression and anxiety). 
serve as a catalyst for negative family interactions. Our design does not allow to differentiate between the aforementioned perspectives.

Anxiety and depression were higher in the ADHD group, as expected, and siblings portrayed intermediate scores. This result is in accordance with other studies that demonstrate not only higher ADHD scores in siblings, but also higher rates of comorbid conditions. ${ }^{34}$ When both depression and anxiety were controlled for (since both potentially contribute to resilience), participants with ADHD continued to show worse resilience levels compared to TDA. We conclude that ADHD in adolescents is associated with lower resilience, even when controlled for confounders often seen in the disorder, e.g., lower socioeconomic levels, lower IQ, anxiety and depression.

\section{Limitations}

The sample size and gender profile of the ADHD group (predominantly male) does not allow generalization of findings to any patient with ADHD, although the predominance of males reflects clinical practice for adolescents. Moreover, even though TDA were similar regarding socioeconomic status and intelligence levels, other potential environmental factors were not investigated (e.g., family structure and educational level of parents, among others) and could also influence the development of each individual's resilience. Finally, in this study, we were not able to distinguish between ADHD itself and a myriad of familial factors (parenting, environment, schooling, etc.) shared by probands with ADHD and their siblings.

\section{Disclosure}

This study received a grant from Shire (PO 8000039476).

Daniel Segenreich and Paulo Eduardo Luiz de Mattos have served on the speaker's bureau and/or acted as consultants for Novartis and Shire; they have received travel awards to participate in scientific meetings from those companies. No other conflicts of interest declared concerning the publication of this article.

\section{References}

1. Kim-Cohen J. Resilience and developmental psychopathology. Child Adolesc Psychiatr Clin N Am. 2007;16:271-83.

2. Assis SG de, Pesce RP, Avanci JQ. Resiliência: enfatizando a proteção dos adolescentes. Porto Alegre: Artmed; 2006.
3. Walsh F. Fortalecendo a resiliência familiar. São Paulo: Roca; 2005.

4. Dell'Aglio DD, Koller SH, Yunes MAM. Resiliência e psicologia positiva: interfaces do risco a proteção. São Paulo: Casa do Psicólogo; 2011.

5. Walsh F. Facilitating family resilience: relational resources for positive youth development in conditions of adversity. In: Unger $M$, editor. The social ecology of resilience. New York: Springer; 2012. p. 173-85.

6. Rutter M. Psychosocial resilience and protective mechanisms. Am J Orthopsychiatry. 1987;57:316-31.

7. Rutter M. Resilience as a dynamic concept. Dev Psychopathol. 2012;24:335-44.

8. Reivich $\mathrm{K}$, Shatte A. The resilience factor: 7 essential skills for overcoming life's inevitable obstacles. New York: Broadway Books; 2002.

9. Koller $\mathrm{SH}$, Lisboa C. Brazilian approaches to understanding and building resilience in at-risk populations. Child Adolesc Psychiatr Clin N Am. 2007;16:341-56.

10. Barkley RA. Transtorno de déficit de atenção/hiperatividade: manual para diagnóstico e tratamento. Porto Alegre: Artmed; 2008.

11. Faraone SV, Biederman J. Can attention-deficit/hyperactivity disorder onset occur in adulthood? JAMA Psychiatry. 2016;73:6556.

12. Peasgood T, Bhardwaj A, Biggs K, Brazier JE, Coghill D, Cooper $\mathrm{CL}$, et al. The impact of ADHD on the health and well-being of ADHD children and their siblings. Eur Child Adolesc Psychiatry. 2016;25:1217-31.

13. Modesto-Lowe V, Yelunina L, Hanjan K. Attention-deficit/ hyperactivity disorder: a shift toward resilience? Clin Pediatr (Phila). 2011;50:518-24.

14. Oddo $L E$, Knouse $L E$, Surman $C B H$, Safren SA. Investigating resilience to depression in adults with ADHD. J Atten Disord. 2018;22:497-505

15. Dvorsky MR, Langberg JM. A review of factors that promote resilience in youth with ADHD and ADHD symptoms. Clin Child Fam Psychol Rev. 2016;19:368-91.

16. Faraone S V, Asherson P, Banaschewski T, Biederman J, Buitelaar JK, Ramos-Quiroga JA, et al. Attention-deficit/hyperactivity disorder. Nat Rev Dis Prim. 2015;1:15020.

17. Fristad MA, Teare M, Weller EB, Weller RA, Salmon P. Study III: development and concurrent validity of the Children's Interview for Psychiatric Syndromes - Parent Version (P-ChIPS). J Child Adolesc Psychopharmacol. 1998;8:221-6.

18. American Psychiatric Association. Diagnostic and Statistical Manual of Mental Disorders (DSM-IV). Washington: APA; 2000.

19. Mattos $P$, Serra-Pinheiro MA, Rohde LA, Pinto D. Apresentação de uma versão em português para uso no Brasil do instrumento MTA-SNAP-IV de avaliação de sintomas do transtorno do déficit de atenção/hiperatividade e sintomas de transtorno desafiador de oposição. Rev Psiquiatr Rio Gd Sul. 2006;28:290-7.

20. Wechsler D. Escala Wechsler de Inteligência para Crianças (WISCIV): manual de instruções para aplicação e avaliação. São Paulo: Casa do Psicólogo; 2013.

21. Spielberger CD. The State-Trait Anxiety Inventory for Children (STAIC). San Antonio: The Psychological Corporation; 1973.

22. Kovacs M. The Children's Depression Inventory (CDI) manual. North Tonawanda: Multi-Health Systems; 1992.

23. Wagnild GM, Young HM. Development and psychometric evaluation of the Resilience Scale. J Nurs Meas. 1993;1:165-78.

24. Pesce RP, Assis SG, Avanci JQ, Santos NC, Malaquias JV, Carvalhaes R. Adaptação transcultural, confiabilidade e validade da escala de resiliência. Cad Saude Publica. 2005;21:436-48.

25. Ahern NR, Kiehl EM, Lou Sole M, Byers J. A review of instruments measuring resilience. Issues Compr Pediatr Nurs. 2006;29:10325.

26. Associação Brasileira de Empresas de Pesquisa (ABEP). Critério Brasil [Internet]. [cited 2019 Jan 16]. http://www.abep.org/ criterio-brasil

27. Regalla MA, Guilherme $P$, Aguilera $P$, Serra-Pinheiro MA, Mattos P. Attention deficit hyperactivity disorder is an independent risk factor for lower resilience in adolescents: A pilot study. Trends Psychiatry Psychother. 2015;37:157-60.

28. Kendall J. Sibling accounts of attention deficit hyperactivity disorder (ADHD). Fam Process. 1999;38:117-36.

29. Mikami AY, Pfiffner LJ. Sibling relationships among children with ADHD. J Atten Disord. 2008;11:482-92. 
30. Chang JPC, Gau SSF. Mother-child relationship in youths with attention-deficit hyperactivity disorder and their siblings. J Abnorm Child Psychol. 2017;45:871-82.

31. Segenreich D, Fortes D, Coutinho G, Pastura G, Mattos P. Anxiety and depression in parents of a Brazilian non-clinical sample of attention-deficit/ hyperactivity disorder (ADHD) students. Braz J Med Biol Res. 2009;42:465-9.

32. Johnston C, Mash EJ. Families of children with attention-deficit/ hyperactivity disorder: review and recommendations for future research. Clin Child Fam Psychol Rev. 2001;4:183-207.

33. Pfiffner LJ, McBurnett K, Rathouz PJ, Judice S. Family correlates of oppositional and conduct disorders in children with attention deficit/hyperactivity disorder. J Abnorm Child Psychol. 2005;33:551-63.

34. Yang L-K, Shang C-Y, Gau SS-F. Psychiatric comorbidities in adolescents with attention-deficit hyperactivity disorder and their siblings. Can J Psychiatry. 2011;56:281-92.

\section{Correspondence:}

Maria Angélica Rates Regalla

Rua Carmem Miranda, 681/203,

21941-340 - Rio de Janeiro, RJ - Brazil

E-mail: angelica.regalla@gmail.com 